\title{
Forthcoming changes to the MRCPsych Part II Examination
}

The following requirements for clinical experience for the MRCPsych Part II Examinations have recently been agreed by the Court of Electors.

\section{Non-psychiatric training accepted towards the training requirements for the Part II Examination}

The Court of Electors has decreed that posts in Obstetrics and Gynaecology may now be accepted as part of the appropriate training towards the MRCPsych Part II examination upon approval by the Sub-Dean for Examinations. Only posts which have been approved for training purposes by the Royal College of Obstetricians and Gynaecologists will be considered.

Section 21 (ii) (a) of the Regulations has been amended as follows:

\section{(a) General Medicine}

One year's full-time post-registration training, in the United Kingdom or the Republic of Ireland, in General Medicine or its sub-specialities provided that this was gained in a post approved by the Royal College of Physicians for purposes of general professional training and substantiated by documentary evidence from the Administrator for General Professional Training at the Royal College of Physicians.

A post in Accident and Emergency or Obstetrics and Gynaecology may be considered by the Dean and Court of Electors provided that full details from the Accident and Emergency or Obstetrics and
Gynaecology Consultant are forwarded. The Dean will look at the medical content of the post before making a decision as to whether it will be accepted as training towards the Examination. Candidates are required to give the full name and address of the relevant Consultant whom the College should approach.

\section{The Critical Review Paper}

The last sitting of the Short Answer Question (SAQ) Paper will take place at the Autumn 1998 examination session. The Critical Review Paper will be introduced at the Spring 1999 MRCPsych Part II examination.

A Working Party has been established to develop the Critical Review Paper and further advice regarding the nature of the examination will be published in late Spring 1997, this information will be circulated to all College Tutors.

\section{The Research Option}

The Court of Electors has agreed that the Research Option should be withdrawn at the end of 1997.

Any queries regarding the above matters should be directed to the Head of Examination Services.

Professor R. H. S. Mindham, Chief Examiner, Royal College of Psychiatrists 